\title{
A 155-plex High-Throughput In Vitro Coregulator Binding Assay for (Anti-)Estrogenicity Testing Evaluated with 23 Reference Compounds
}

\author{
Si Wang ${ }^{1,2}$, René Houtman ${ }^{3}$, Diana Melchers ${ }^{3}$, Jac Aarts ${ }^{1,2}$, Ad Peijnenburg ${ }^{2}$, \\ Rinie van Beuningen ${ }^{3}$, Ivonne Rietjens ${ }^{1}$, and Toine F. Bovee ${ }^{2}$ \\ ${ }^{1}$ Division of Toxicology, Wageningen University and Research Centre, Wageningen, The Netherlands; ${ }^{2}$ Toxicology \& \\ Bioassays, RIKILT - Institute of Food Safety, Wageningen University and Research Centre, Wageningen, The Netherlands; \\ ${ }^{3}$ PamGene International B.V., 's-Hertogenbosch, The Netherlands
}

\section{Summary}

To further develop an integrated in vitro testing strategy for replacement of in vivo tests for (anti-) estrogenicity testing, the ligand-modulated interaction of coregulators with estrogen receptor $\alpha$ was assessed using a PamChip $®$ plate. The relative estrogenic potencies determined, based on ER $\alpha$ binding to coregulator peptides in the presence of ligands on the PamChip $\circledast$ plate, were compared to the relative estrogenic potencies as determined in the in vivo uterotrophic assay. The results show that the estrogenic potencies predicted by the 57 coactivators on the peptide microarray for 18 compounds that display a clear E2 dose-dependent response (goodness of fit of a logistic dose-response model of 0.90 or higher) correlated very well with their in vivo potencies in the uterotrophic assay, i.e., coefficient of determination values for 30 coactivators higher than or equal to 0.85. Moreover, this coregulator binding assay is able to distinguish ER agonists from ER antagonists: profiles of selective estrogen receptor modulators, such as tamoxifen, were distinct from those of pure ER agonists, such as dienestrol. Combination of this coregulator binding assay with other types of in vitro assays, e.g., reporter gene assays and the H295R steroidogenesis assay, will frame an in vitro test panel for screening and prioritization of chemicals, thereby contributing to the reduction and ultimately the replacement of animal testing for (anti-)estrogenic effects.

Keywords: estrogenicity, coregulator, peptide microarray, in vivo uterotrophic assay, alternative in vitro method

\begin{tabular}{|c|c|c|c|}
\hline \multicolumn{4}{|c|}{ Abbreviations } \\
\hline $2,4,5-\mathrm{T}$ & 2,4,5-trichlorophenoxyacetic acid & LBD & ligand-binding domain \\
\hline $\mathrm{CV}$ & coefficient of variation & MIE & molecular initiating event \\
\hline DMSO & dimethyl sulfoxide & NCOA1 & nuclear receptor coactivator 1 \\
\hline E2 & $17 \beta$-estradiol & NCOR1 & nuclear receptor corepressor 1 \\
\hline EE2 & $17 \alpha$-ethinyl estradiol & NR & nuclear receptor \\
\hline EPA & $\begin{array}{l}\text { Environmental Protection Agency, } \\
\text { United States }\end{array}$ & OMIY-bisphenol & $\begin{array}{l}\text { 4,4'-(octahydro-4,7-methano-5h- } \\
\text { inden-5-ylidene)bisphenol }\end{array}$ \\
\hline ER & estrogen receptor & $\mathrm{R}^{2}$ & coefficient of determination \\
\hline GST & glutathione S-transferase & $\mathrm{REACH}$ & Registration, Evaluation, Authorization \\
\hline ICCVAM & $\begin{array}{l}\text { Interagency Coordinating Committee } \\
\text { on the Validation of Alternative Methods }\end{array}$ & SERMs & $\begin{array}{l}\text { and restriction of Chemicals } \\
\text { selective estrogen receptor modulators }\end{array}$ \\
\hline
\end{tabular}

Received August 14, 2012; accepted in revised form January 2, 2013 


\section{Introduction}

Estrogens exert their physiological effects mainly through activation of the estrogen receptor (ER) in target cells (Couse and Korach, 1999; Heldring et al., 2007). Although two main forms of ER exist, ER $\alpha$ and ER $\beta$, in (reproduction) toxicology the primary attention goes to the $\mathrm{ER} \alpha$, as it is the dominating type in breast and uterus tissue (Gustafsson, 1999; Harris et al., 2002). Moreover, with respect to regulatory purposes, the focus is on ER $\alpha$ because binding and induction of ER $\alpha$ is implicated as a key molecular initiating event (MIE) in estrogenicity-related adverse endpoints. $\mathrm{ER} \alpha$ and $\mathrm{ER} \beta$, like all the members of the nuclear receptor (NR) super-family, are ligand-dependent transcription factors that work in concert with transcriptional coregulators to control target gene transcription. Upon ligand binding, the ligand-binding domain (LBD) undergoes a conformational change that leads to receptor dimerization, translocation of the ER from cytosol to nucleus, and binding to estrogen-responsive elements. Moreover, as a result of the intramolecular conformational changes induced by ligand binding, the affinity of the ER for coregulator proteins is changed, resulting in recruitment or release of transcriptional coactivator or corepressor proteins, respectively, that enhance or repress the interaction of RNA polymerase II with estrogenresponsive gene promoters and all of the subsequent reactions needed to actually induce or repress transcription of target genes (Klinge, 2000; Ascenzi et al., 2006).

In general, the transcriptional coregulator family consists of coactivators, which augment the activity of the receptors, and corepressors that mediate the repressive effects of receptors (Johnson and O'Malley, 2012; McKenna et al., 1999). The most studied group of ER $\alpha$ coactivators includes the $\mathrm{p} 160$ protein family, consisting of NCOA1 (SRC-1), NCOA2 (SRC-2), and NCOA3 (SRC-3), which interact with the activation function-2 (AF-2) domain of agonist-bound ERs through multiple LXXLL motifs present in these coactivator proteins (where $\mathrm{L}$ is leucine and $X$ is any amino acid) (Klinge, 2000; Metzler et al., 2001). Structural analysis of nuclear receptor (NR) LBDs has established that agonist binding stabilizes the AF-2 helix in an active conformation to form a charge clamp pocket, which is permissive for interactions with LXXLL motifs. In contrast, ER antagonists affect the positioning of the AF-2's mobile Cterminal helix (helix 12) to form a large binding pocket that interacts with the LXXXIXXXL motifs of corepressor proteins (where $\mathrm{I}$ is isoleucine) such as nuclear receptor corepressor 1 (NCOR1) and nuclear receptor corepressor 2 (NCOR2), thereby disrupting the LXXLL-binding site and preventing coactivator recruitment (Shiau et al., 1998; Brzozowski et al., 1997; Kong et al., 2005).

The standard test for disruption of normal estrogen function is the in vivo uterotrophic assay, i.e., a test with immature or ovariectomized rodents using uterus weight as the crucial read-out parameter (Clode, 2006; Owens and Ashby, 2002). With a view to the REACH Regulation (EC, 2006) and the need to reduce, refine, and replace the use of experimental animals for safety testing (3Rs), modulation of ER activity is usually quantitatively analyzed by assaying ER binding, ER-controlled reporter genes, or other downstream events such as estrogen receptor-mediated cell proliferation (Bovee and Pikkemaat, 2009). ER binding assays are rapid and easy to perform; one of the main drawbacks, however, is that these assays are unable to distinguish receptor agonists from receptor antagonists. Moreover, the rat uterine cytosol ER binding assay, currently listed as part of the Environmental Protection Agency's (EPA) Endocrine Disruptor Screening Program Tier 1 screening battery, still requires the use of animals as a source of ERs. Unlike receptor binding assays, reporter gene assays can distinguish between agonist and antagonist activity. Several reporter gene assays have been developed and applied as screening tools to determine the estrogenic/ anti-estrogenic activities of compounds, as they are cheap, fast, robust, and have been shown to produce relevant and reliable outcomes (Bovee et al., 2009; van der Burg et al., 2010; Plotan et al., 2012). Proliferation assays and low-density DNA microchipbased analysis of marker gene expression also have been shown to provide valuable tools for estrogenicity testing, and outcomes correlate well with the in vivo uterotrophic assay (Wang et al., 2012, 2013), but these two assays are laborious and require 3-6 days. Therefore, they are not ideal for the large-scale testing of chemicals with respect to initiatives such as REACH.

Thus far, studying nuclear receptor interactions with coregulators has been performed mainly for theoretical reasons and for drug development (Lonard and O'Malley, 2012; Hsia et al., 2010; McDonnell and Wardell, 2010). However, a high-throughput in vitro assay enabling quantification of coactivator or corepressor recruitment by receptors upon ligand binding would have the potential to add relevant information to an integrated in vitro strategy for (anti-)estrogenicity testing, aiming at prioritization of chemicals and reduction of in vivo animal experiments needed for initiatives such as REACH. In the present study, the ligand-modulated interaction of coregulators with $\mathrm{ER} \alpha$ was assessed using a PamChip® plate consisting of 96 identical arrays, each array containing 155 immobilized nuclear receptor (NR) coregulator peptides harboring either LXXLL (coactivator) or LXXXIXXXL (corepressor) motifs. A set of 23 reference compounds was tested in the coregulator binding assay based on the PamChip ${ }^{\circledR}$ plate. Twenty-one of these compounds were selected from the 78 compounds listed by the Interagency Coordinating Committee on the Validation of Alternative Methods (ICCVAM) for validation of in vitro ER binding and transcriptional activation assays assays (ICCVAM, 2003). The objective was to determine to what extent this coregulator binding assay correctly predicts the estrogenic/anti-estrogenic activities and potencies of the test compounds when compared to the outcomes obtained in the in vivo uterotrophic assay.

\section{Materials and methods}

\section{Chemicals}

17 $\beta$-Estradiol (E2), diethylstilbestrol, meso-hexestrol, coumestrol, dienestrol, zearalenone, corticosterone, tamoxifen, 4-hydroxytamoxifen, bisphenol A, ethyl paraben, o,p'-DDT, $p$-n-nonylphenol, and apigenin were obtained from Sigma-Aldrich Chemie B.V. (Zwijndrecht, The Netherlands). $17 \alpha$-Ethinyl estradiol (EE2), progesterone, and testosterone 
(T) were purchased from Steraloids (Newport, RI, USA), while genistein was obtained from Apin Chemicals (Abingdon, Oxon, UK). 4,4'-(Octahydro-4,7-methano-5h-inden-5-ylidene) bisphenol (OMIY-bisphenol) was from Acros Organics (Fisher Emergo B.V., Landsmeer, The Netherlands). Dimethyl sulfoxide (DMSO) was purchased from Merck (Darmstadt, Germany). Kepone and 2,4,5-trichlorophenoxyacetic acid (2,4,5-T) were obtained from Dr. Ehrenstorfer GmbH (Augsburg, Germany). Butylbenzyl phthalate and di- $n$-butyl phthalate were purchased from TCI Europe N.V. (Zwijndrecht, Belgium).

\section{Nuclear receptor-coregulator interaction profiling}

Ligand-modulated interaction of coregulators with ER $\alpha$-LBD was assessed using a PamChip ${ }^{\circledR}$ plate described previously (Houtman et al., 2012). The PamChip ${ }^{\circledR}$ plate consists of 96 identical arrays, each array containing 155 NR coregulator peptides harboring either LXXLL (coactivator) or LXXXIXXXL (corepressor) motifs (PamGene International B.V.,'s-Hertogenbosch, The Netherlands). The coregulator peptides are immobilized on a porous metal oxide carrier by piezo technology as previously used in kinase assays (Hilhorst et al., 2009; Lemeer et al., 2007). The PamChip ${ }^{\circledR}$ plate was used in combination with the glutathione S-transferase (GST)labeled ER $\alpha$-LBD to screen dilution series of a set of 23 compounds. The peptide microarray was incubated with the test solution containing ER $\alpha$-LBD-GST in the absence or presence of ligand by pumping the sample up and down the three-dimensional metal oxide carrier (Fig. 1A). In short, assay mixtures were prepared on ice in a master 96-well plate with $5 \mathrm{nM}$ GST-tagged human ER $\alpha$ LBD (PamGene International B.V.), 25 nM Alexa 488-conjugated GST antibody (Invitrogen, Breda, The Netherlands), and ligand at the indicated concentration in reaction buffer $(20 \mathrm{mM}$ Tris, $\mathrm{pH}$ 7.5, $500 \mathrm{mM} \mathrm{NaCl}, 0.2 \% \mathrm{BSA}, 0.05 \%$ Tween-20). All assays were performed in a fully automated PamStation ${ }^{\circledR}-96$ (PamGene International B.V.) at $20^{\circ} \mathrm{C}$ applying two cycles per minute. The initial blocking was carried out by incubating each array for 20 cycles with $25 \mu \mathrm{l}$ blocking buffer (TBS with $1 \%$ BSA, $0.01 \%$ Tween-20, and $0.3 \%$ skimmed milk powder). Subsequently, the blocking buffer was removed and $25 \mu 1$ assay mix was transferred to each array and incubated for 80 cycles ( 40 min). Eight concentrations with tenfold serial dilution in dimethyl sulfoxide (DMSO; final concentration $2 \%$ ) of each compound were tested in singular. After removal of the unbound receptor by washing the plate with $25 \mu 1 \mathrm{TBS}$, tiff images were obtained by a CCD camera-based optical system integrated in the PamStation ${ }^{\circledR}$ 96 instrument. The total set of compounds was tested over two PamChip ${ }^{\circledR}$ plates and by using E2 as a reference compound on each plate.

\section{Data analysis}

Image analysis was performed using BioNavigator software (PamGene International B.V.), which performs automated array grid finding and subsequent quantification of signal and local background for each individual peptide. In short, the boundaries of a spot are determined and the median fluorescent signal is quantified within the spot (signal) as well as that in a defined area surrounding it (background). The signal-minus-background value is used subsequently as the quantitative parameter of bind- ing. Ligand dose-response relations were analyzed using the DRC package in $\mathrm{R}$ (version 2.12.0, http://www.r-project.org). A sigmoidal 4-parameter logistic model was fitted to the doseresponse data and the goodness-of-fit parameter and $\mathrm{EC}_{50}$ values as calculated by the DRC package were recorded. Relative binding potency $(\mathrm{RBP})$ values were obtained from the ratio of the concentration of E2 needed to achieve $50 \%$ of maximal ER $\alpha$ LBD binding to the coregulator and the concentration of the test compounds required to achieve a similar effect. This ratio subsequently is multiplied by 100 . The RBP value of E2 is thus 100 , resulting in a $\log \mathrm{RBP}$ of 2.0. A cut-off value of -5.0 is listed for compounds showing no effect. The estrogenicity data used for comparisons with the current ER $\alpha$-coregulator binding data were ER binding data in the review published by ICCVAM (2003), and the BG1Luc ER TA data reported by the National Toxicology Program (NTP) Interagency Center for the Evaluation of Alternative Toxicological Methods (NICEATM) and ICCVAM (2011). For comparison of the presented in vitro ER $\alpha$-coregulator binding data with estrogenicity in vivo, uterotrophic assay data were used that were derived from the Endocrine Disruptor Knowledge Base (EDKB), designed and produced by the National Center for Toxicological Research, USA (Ding et al., 2010).

\section{Results}

Twenty-one of the 23 compounds tested were selected from the 78 compounds listed by ICCVAM for validation of in vitro ER binding and transcriptional activation assays, representing the main groups of compounds with estrogenic activity, i.e., natural steroids, synthetic steroids, flavonoids, phenols, organochlorines, and phthalates (ICCVAM, 2003). Figure 1B shows the dose-response curves of ER $\alpha$-LBD binding to the 155 coregulator peptides as induced by $17 \beta$-estradiol (E2). Most of the coregulator spots showed an increased binding signal with increasing E2 concentrations, e.g., NCOA1_677_700, NCOA2_628_651 and NCOA3_673_695, which all have the LXXLL motif signature sequence and are known to function as coactivators. As an example, the E2-induced dose-response curve of ER $\alpha$-LBD binding to coactivator peptide NCOA1_677_700 is shown in Figure 1C. The lowest concentration of the potent E2 that resulted in a detectable binding of ER $\alpha$-LBD to NCOA1_677_700 was $0.19 \mathrm{nM}$, reaching a half maximal binding level $\left(\mathrm{EC}_{50}\right)$ at approximately $0.7 \mathrm{nM}$ and binding was saturated above $20 \mathrm{nM}$. However, not all the coactivator peptides immobilized on the peptide microarray showed an E2 concentration-dependent binding response of ER $\alpha$-LBD, e.g., chromodomain-helicase-DNA-binding protein 9 (CHD9_855_877) and centromere protein R (CENPR_1_18) did not show any E2-induced binding. As expected, the corepressor peptides with the LXXXIXXXL motif, e.g., NCOR1_1925_1946 and NCOR2_2330_2352, did not show an ER $\alpha$-LBD binding response upon co-incubation with E2. E2 was used as a reference compound on each of the two PamChip ${ }^{\circledR}$ plates. To assess the reproducibility of the assay, all duplicate E2 data together were plotted against each other, which resulted in a correlation with coefficient of determination $\left(\mathrm{R}^{2}\right)$ of 0.944 . Moreover, the coefficient of variation $(\mathrm{CV})$ was calculated at a binding-saturating E2 


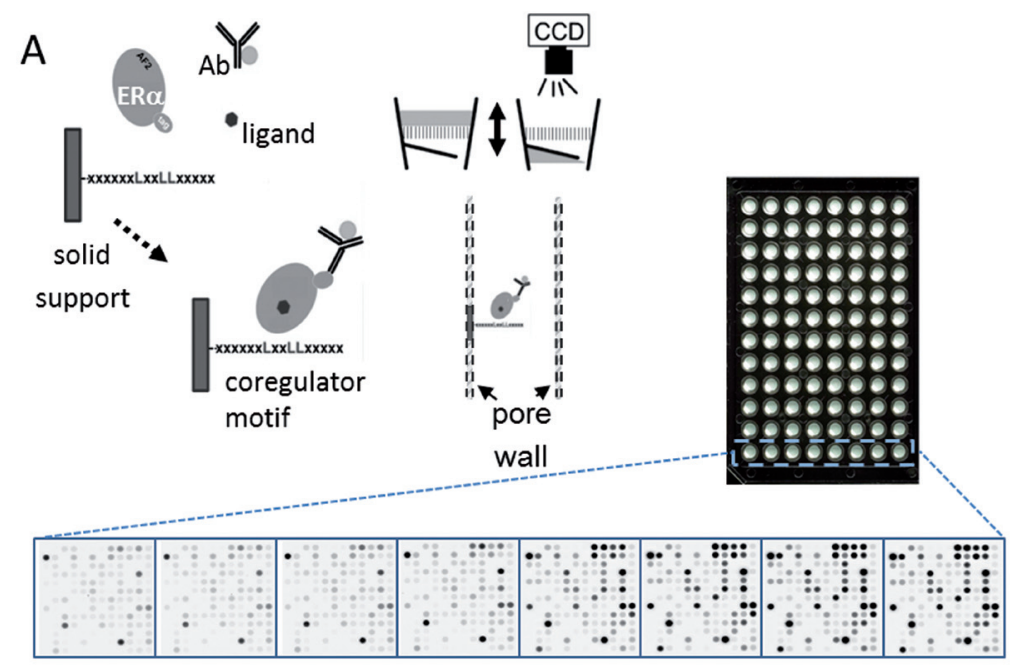

C

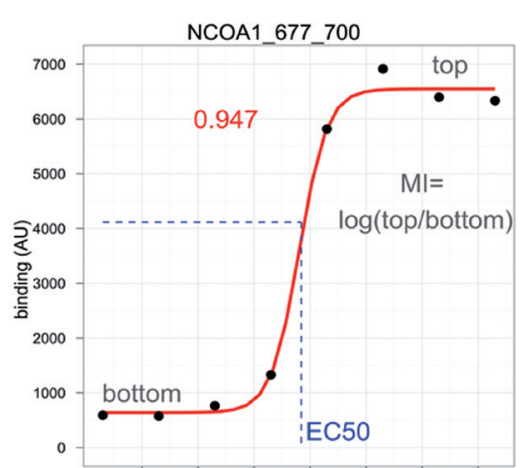

B
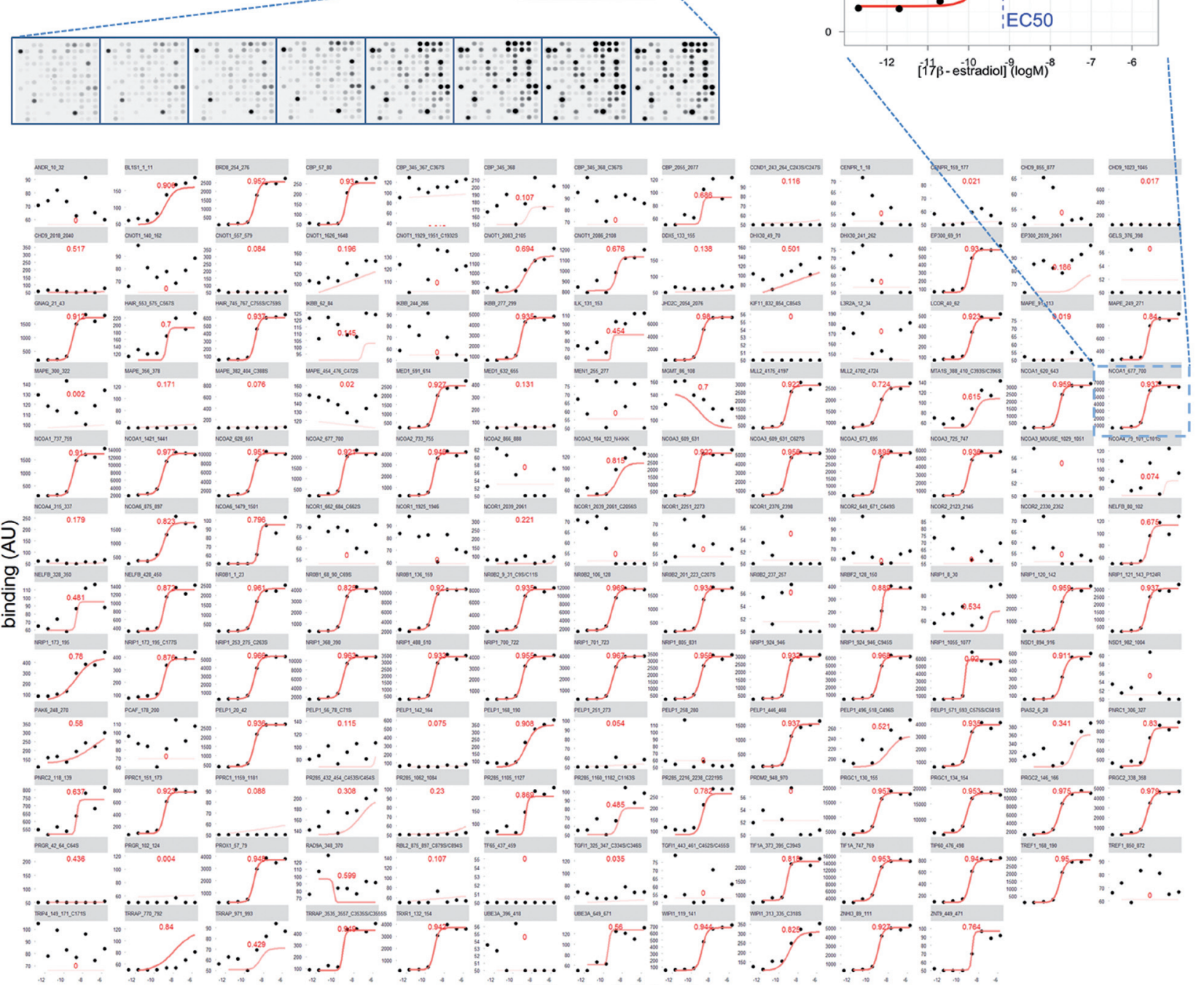

[17ß-estradiol] $(\log M)$

Fig. 1: Analysis of ERa-LBD binding to coregulators induced by $17 \beta$-estradiol

A. Schematic overview of the PamChip peptide microarray technology. B. Dose-response curves for ERa-LBD binding to the 155 coregulator-derived receptor binding motifs induced by $17 \beta$-estradiol. C. Enlargement of the dose-response curve for $17 \beta$-estradiolinduced binding of ERa-LBD to coactivator NCOA1_677_700. 
concentration $(20 \mathrm{nM})$ over each pair of duplicate E2 data. This resulted in a median intraplate $\mathrm{CV}$ of $8.0 \%$.

All known estrogenic compounds tested on the peptide microarray (e.g., EE2, dienestrol, diethylstilbestrol, and mesohexestrol) resulted in coregulator binding profiles similar to that of E2. Except for testosterone, the negative controls (i.e., corticosterone and progesterone) showed no statistically significant binding changes compared with the solvent control DMSO (data not shown), while the selective estrogen receptor modulators (SERMs), i.e., tamoxifen, 4-hydroxytamoxifen, and (OMIYbisphenol), showed a completely different coregulator binding profile. As shown in Figure 2, compared with the solvent control DMSO and the known estrogen agonists, tamoxifen strongly inhibited binding of ER $\alpha$-LBD to almost all coactivator peptides, and similar repression of binding was observed with 4-hydroxytamoxifen and OMIY-bisphenol (see supplementary files 1 and 2 at www.altex-edition.org). Surprisingly, no binding was observed for these SERMs to the corepressors present on the peptide microarray. Figure 3 shows the doseresponse curves of 23 compounds based on three coregulators NCOA1_677_700, NRIP1_173_195, and PNRC2_118_139, resulting in curve fittings with a goodness of fit of $0.94,0.78$ and 0.63 , respectively for E2. The relative coregulator binding potency (RBP) values of these 23 compounds were calculated for these three coactivator peptides and listed in Table 1. To allow comparison with the observed in vivo effects, the median $\log$ relative potency $(\log \mathrm{RP})$ of these compounds as determined previously in the in vivo uterotrophic assay with mice or rats are included and shown in Table 1. Figure 4 shows the comparison between the $\operatorname{logRP}$ values as determined in the in vivo uterotrophic assay and the $\operatorname{logRBP}$ values as determined in the coregulator binding assay based on coactivators of NCOA1_677_700, NRIP1_173_195, and PNRC2_118_139. Although tamoxifen had a clear effect on the binding of these three coactivators, its effect is mostly opposite to that of E2. As tamoxifen is a SERM that mainly shows its antagonistic properties when tested on the current coregulator binding assay (Fig. 2), it is not possible to compare its observed antagonistic binding effects with the agonistic binding effects obtained with E2. The same is valid for the SERMs 4-hydroxytamoxifen and OMIY-bisphenol, which also show antagonistic coregulator binding effects. Therefore, for the comparison of the in

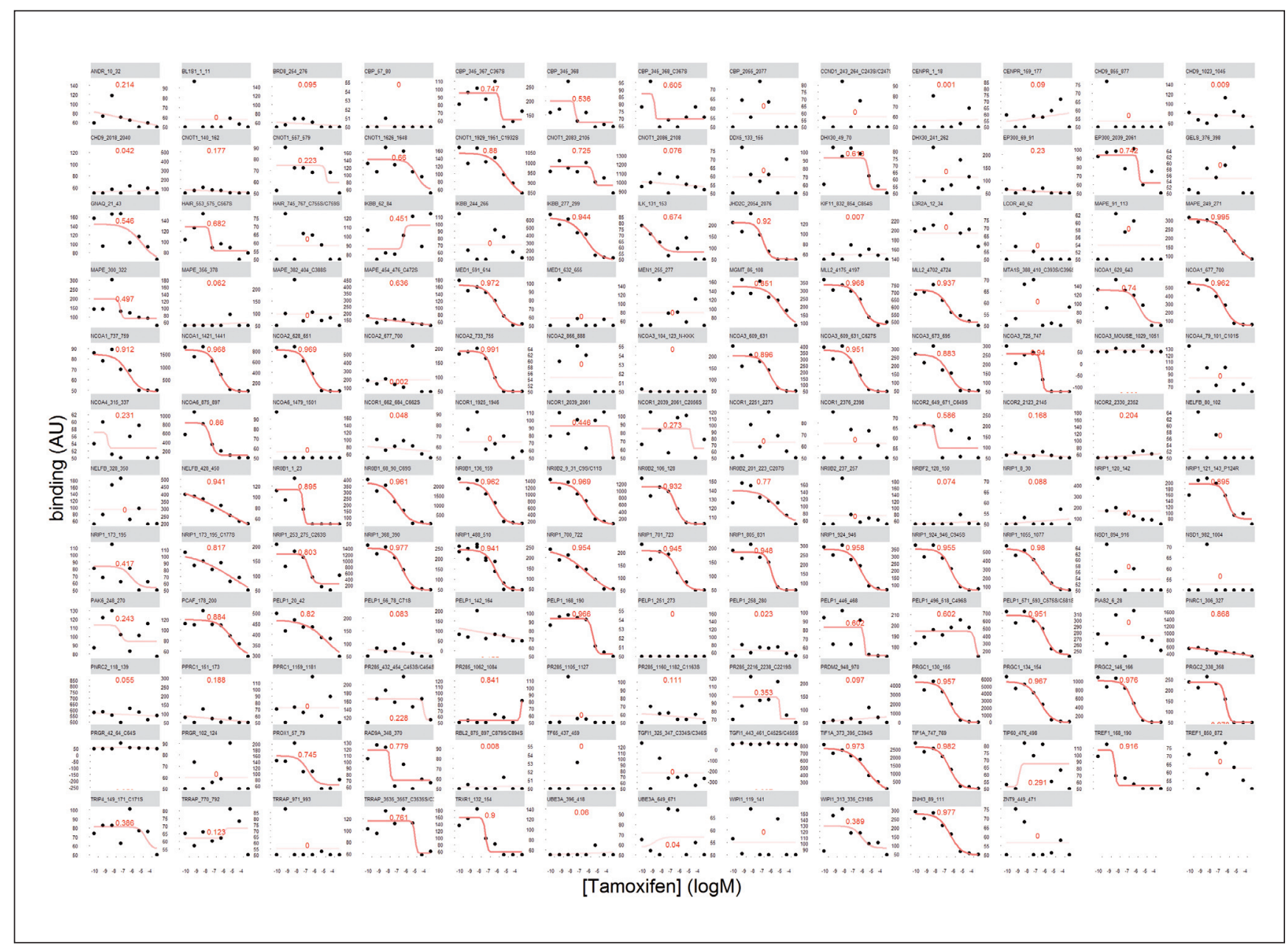

Fig. 2: Analysis of ERa-LBD binding to coregulators induced by tamoxifen 
vitro coregulator binding assay with the in vivo uterotrophic assay, tamoxifen, 4-hydroxytamoxifen, and OMIY-bisphenol were left out (Fig. 4 and Tab. 2). Instead, to provide an overall measure of the antagonistic binding potency for the SERMs, the median of the $\mathrm{IC}_{50}$ values were calculated over all those coregulators showing a good fit of the standard dose-response model used (goodness-of-fit of a sigmoidal 4-parameter logistic model of 0.85 or higher). The number of coregulators meeting this requirement are 29 for OMIY-bisphenol, 41 for tamoxifen and 50 for 4-hydroxytamoxifen, resulting in median $\mathrm{IC}_{50}$ of $1.39 \times 10^{-7} \mathrm{M}, 2.55 \times 10^{-7} \mathrm{M}$, and $1.82 \times 10^{-9} \mathrm{M}$, respectively. In addition to the SERMs, apigenin and 2,4,5-T also were left out for the comparison of the coregulator binding assay with the in vivo uterotrophic assay. For 2,4,5-T there are no uterotrophic data available in the literature, and although apigenin has been shown to display estrogenic activities in in vitro reporter gene assays (Willemsen et al., 2004; Long et al., 2008), it was negative for estrogenic effects on the uterus in the uterotrophic assay. However, this is probably due to the poor bioavailability of apigenin in rodents (Breinholt et al., 2000). In the coregulator binding assay apigenin clearly induced binding of ER $\alpha$-LBD to similar coactivators as E2. Figure 4 illustrates that using all dose-response curves and corresponding coregulator binding potencies $(\log \mathrm{RBP})$, the NCOA1_677_700 coactivator peptide-based $\operatorname{logRBP}$ values correlated very well with the in vivo relative potencies $(\log \mathrm{RP})$, values determined in the uterotrophic assay $\left(\mathrm{R}^{2}=0.89, \mathrm{p}<0.0001, \mathrm{n}=18\right)$. Binding of coactivator NRIP1_173_195, with an intermediate E2 dose-response

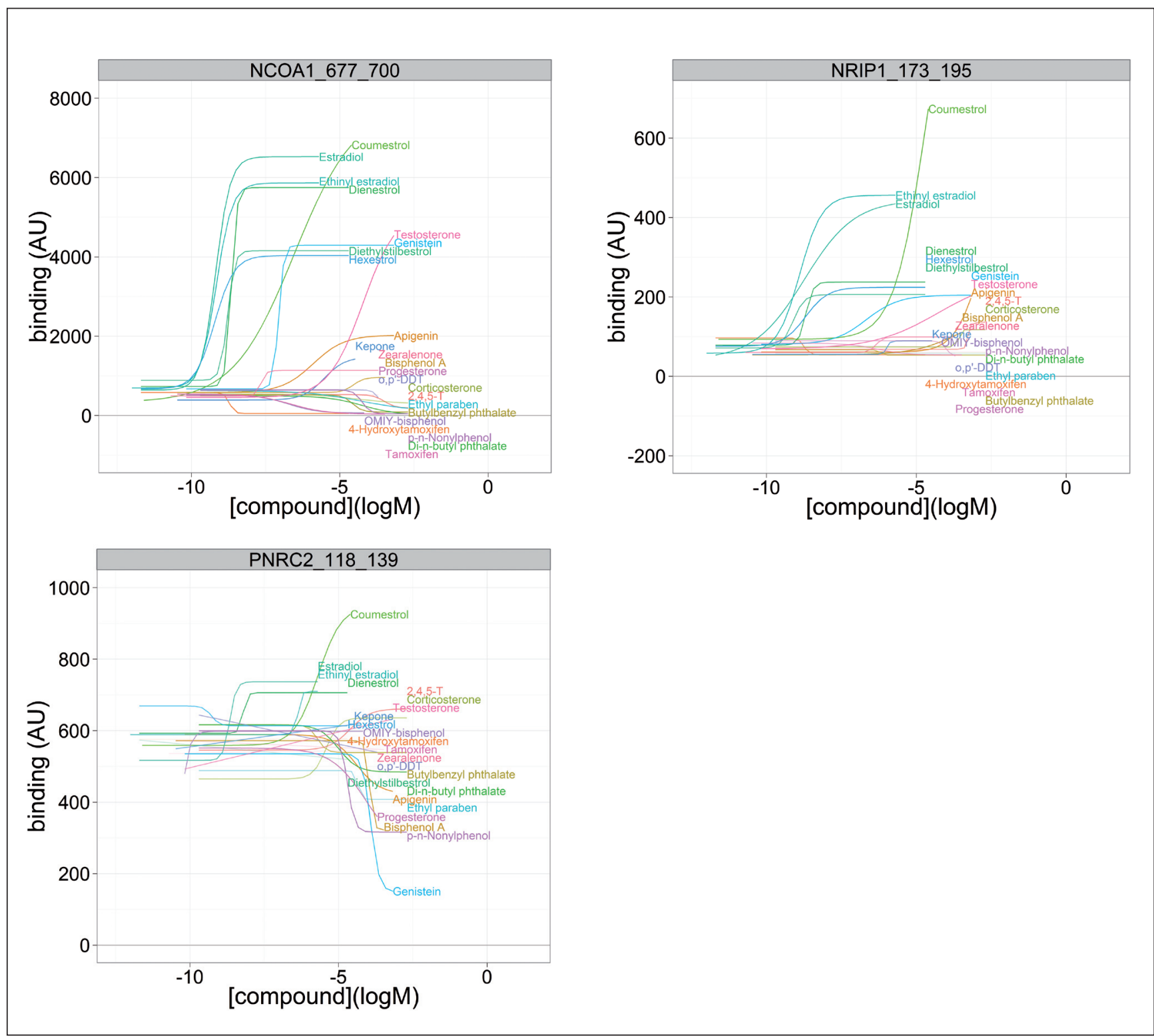

Fig. 3: Dose-response curves of ERa-LBD binding to the NCOA1_677_700, NRIP1_173_195, and PNRC2_118_139 coactivator peptides for the 23 compounds 
curve goodness of fit of 0.78 , still resulted in a relatively good correlation $\left(\mathrm{R}^{2}=0.79, \mathrm{p}<0.0001, \mathrm{n}=18\right)$, whereas the binding of PNRC2_118_139, which has a relatively low E2 dose-response curve goodness of fit of 0.63 , showed no correlation with the in vivo determined $\operatorname{logRP}$ values of the uterotrophic assay $\left(\mathrm{R}^{2}=0.01, \mathrm{p}=0.698, \mathrm{n}=18\right)$.

Next, the dose-response curve goodness-of-fit value for each coregulator of each compound was calculated. Out of the 155 coactivator peptides, 57 gave E2 curve fittings higher than or equal to 0.9. The determined $\mathrm{EC}_{50}$ values for $\mathrm{E} 2$ derived from these 57 curves were all in the low nanomolar range and showed a median $\mathrm{EC}_{50}$ of $0.9 \mathrm{nM}$. Subsequently, similar to what is shown in Table 1 and Figure 4, the $\operatorname{logRBP}$ values based on these 57 coactivators were calculated for each compound and correlated with different relative potency values from literature, i.e., $\log R B A$ values obtained in the ER binding assay $(n=19)$, $\operatorname{logREP}$ values obtained in the BG1Luc ER transcriptional activation assay $(n=16)$, and $\log R P$ values obtained in the uterotrophic assay $(n=18)$. The resulting $\mathrm{R}^{2}$ values are shown in Table 2. In general, the estrogenic potencies predicted by the coregulator binding assay correlated well with the ER binding assay, as well as with the BG1Luc ER transcriptional activation assay, which was recently approved by OECD as a test method for identifying estrogen receptor agonists and antagonists. As shown in Table 2, 33 coactivators showed an $\mathrm{R}^{2}$ value higher than or equal to 0.80 with the ER binding assay, and 32 coactivators showed an $\mathrm{R}^{2}$ value higher than or equal to 0.80 with the BG1Luc ER transcriptional activation assay. For the correlation with the in vivo uterotrophic assay, in total 48 coactivators showed an $\mathrm{R}^{2}$ value higher than or equal to 0.8 , and among these, 30 coactivators showed an $\mathrm{R}^{2}$ value higher than or equal to 0.85 (e.g., NCOA1_677_700, NCOA3_673_695, and NR0B2_106_128). A low correlation coefficient was observed for BL1S1_1_11 ( $\left.\mathrm{R}^{2}=0.49\right)$.

\section{Discussion}

The aim of the present study was to investigate the potential of the PamChip ${ }^{\circledR}$ plate based coregulator binding assay as part of an integrated in vitro testing strategy for detection of (anti-) estrogenic activity. To this end a set of 23 reference compounds was investigated using the peptide microarray in combination with the GST-labeled ligand-binding domain of ER $\alpha$. As a concentration series consisting of eight concentrations with tenfold serial dilution was tested for each compound, the dose-response relation could be determined with great statistical accuracy as demonstrated by the goodness of fit data. With a median $\mathrm{EC}_{50}$ of $0.9 \mathrm{nM}$, an intraplate coefficient of variation of $8.0 \%$ at a saturating binding concentration of $20 \mathrm{nM} \mathrm{E2}$, and an excellent correlation $\left(\mathrm{R}^{2}=0.944\right)$ between duplicate $\mathrm{E} 2$ measurements, the sensitivity and reproducibility of the coregulator binding assay was well within the range observed for other commonly used in vitro ER functional assays. Moreover, the coregulator binding assay uses fluorescence as an endpoint measurement, which offers several advantages in comparison to radioligand receptor binding assays, such as low costs and avoiding problems related to health hazards of radiation exposure and radioactive waste disposal. Dose-response analysis of the binding of ER $\alpha$-LBD to coregulators in the presence of the ligand showed that the known estrogens (e.g., EE2, dienestrol, diethylstilbestrol, and meso-hexestrol) resulted in coregulator binding profiles similar to the reference compound E2, but each compound showed its own specific potency resulting in different EC $_{50}$ values. Except for testosterone, the negative controls (i.e., corticosterone and progesterone) showed no significant binding changes compared with the solvent control DMSO. The SERMs tested on the peptide microarray (i.e., tamoxifen, 4-hydroxytamoxifen, and OMIY-bisphenol) showed no binding on the corepressors present on the peptide microarray and showed decreased coac-

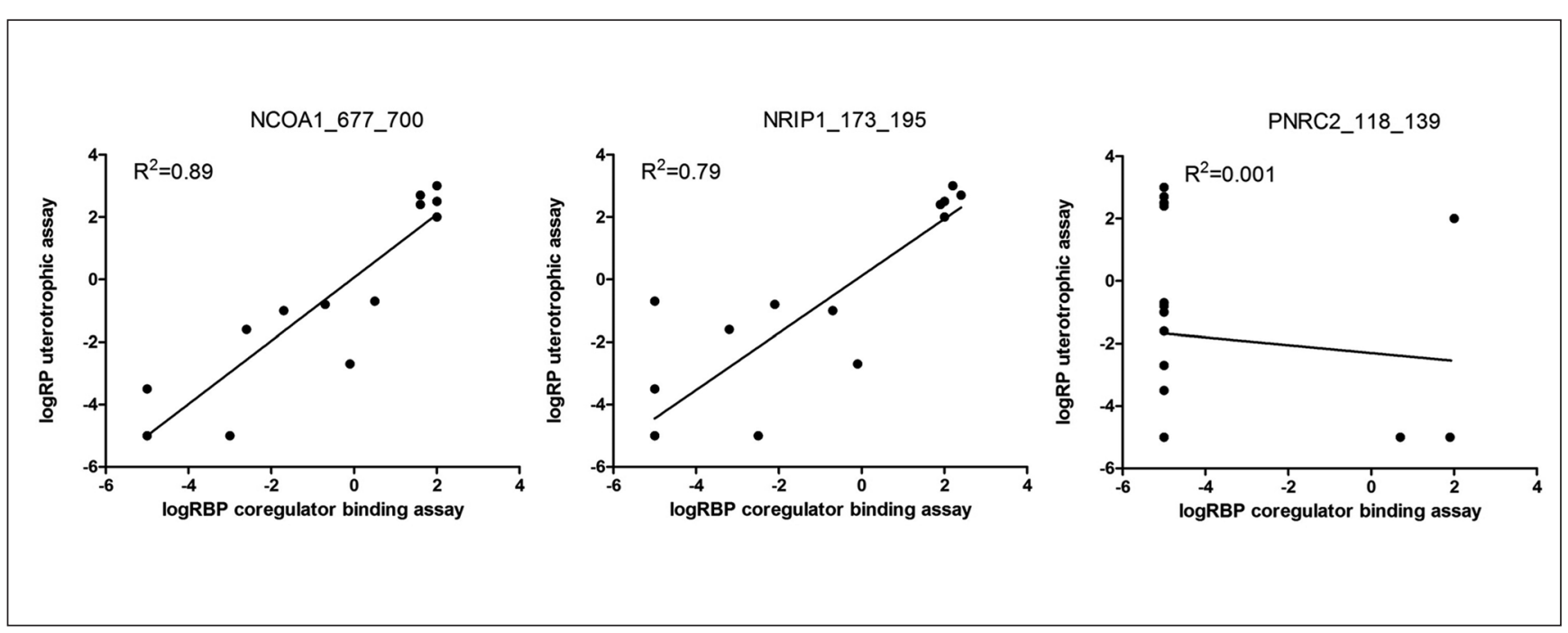

Fig. 4: Comparison of the log relative potencies (logRP) measured in the in vivo uterotrophic assay with the log relative coregulator binding potency (IogRBP) as determined in the coregulator binding assay for the NCOA1_677_700, NRIP1_173_195, and PNRC2_118_139 coactivator peptides for the 18 compounds

Tamoxifen, 4-hydroxytamoxifen, OMIY-bisphenol, apigenin and 2,4,5-T were excluded from the comparison. 
Tab. 1: Comparison of the relative potencies obtained in the ER binding assay, BG1Luc ER transcriptional activation assay, and in vivo uterotrophic assay with those obtained in the coregulator binding assay for the 23 compounds

\begin{tabular}{|c|c|c|c|c|c|c|c|c|}
\hline \multicolumn{2}{|l|}{ Compounds } & \multirow[t]{2}{*}{ CAS nr. } & \multirow{2}{*}{$\begin{array}{c}\text { ER binding } \\
\text { assay } \\
\log \mathrm{RBA}^{\mathrm{a}}\end{array}$} & \multirow{2}{*}{$\begin{array}{l}\text { BG1Luc } \\
\text { ER TA } \\
\text { logREPe }\end{array}$} & \multirow{2}{*}{$\begin{array}{c}\text { Uterotrophic } \\
\text { assay } \\
\operatorname{logRPf}^{f}\end{array}$} & \multicolumn{3}{|c|}{$\begin{array}{c}\text { Coregulator binding assay } \\
\text { logRBPh }\end{array}$} \\
\hline & & & & & & $\begin{array}{l}\text { NCOA1 } \\
677 \_700\end{array}$ & $\begin{array}{l}\text { NRIP1_ } \\
\text { 173_195 }\end{array}$ & $\begin{array}{l}\text { PNRC2 } \\
118 \_139\end{array}$ \\
\hline \multirow{8}{*}{$\begin{array}{l}\text { Steroids } \\
\text { and synthetic } \\
\text { estrogens }\end{array}$} & $17 \beta$-Estradiol & $50-28-2$ & 2.0 & 2.0 & 2.0 & 2.0 & 2.0 & 2.0 \\
\hline & $\begin{array}{l}\text { 17a-Ethinyl } \\
\text { estradiol }\end{array}$ & $57-63-6$ & 2.2 & 1.7 & 3.0 & 2.0 & 2.2 & -5.0 \\
\hline & Diethylstilbestrol & $56-53-1$ & 2.1 & 1.2 & 2.7 & 1.6 & 2.4 & -5.0 \\
\hline & Dienestrol & $84-17-3$ & $2.0^{\mathrm{b}}$ & NA & 2.4 & 1.6 & 1.9 & -5.0 \\
\hline & meso-Hexestrol & $84-16-2$ & 2.4 & 1.3 & 2.5 & 2.0 & 2.0 & -5.0 \\
\hline & Corticosterone & $50-22-6$ & $-5.0^{c}$ & -5.0 & -5.0 & -5.0 & -5.0 & -5.0 \\
\hline & Progesterone & $57-83-0$ & -3.5 & -5.0 & -5.0 & -5.0 & -5.0 & -5.0 \\
\hline & Testosterone & $58-22-0$ & -1.6 & -3.2 & -5.0 & -3.0 & -2.5 & 0.7 \\
\hline \multirow{4}{*}{$\begin{array}{l}\text { Phytoestrogens } \\
\text { (natural products) }\end{array}$} & Coumestrol & $479-13-0$ & 1.1 & -2.6 & -0.8 & -0.7 & -2.1 & -5.0 \\
\hline & Genistein & $446-72-0$ & 0.2 & -2.9 & -2.7 & -0.1 & -0.1 & -5.0 \\
\hline & Apigenin & $520-36-5$ & 0.1 & -3.6 & -5.0 & -1.3 & -3.8 & -5.0 \\
\hline & Zearalenone & $17924-92-4$ & 1.2 & NA & -0.7 & 0.5 & -5.0 & -5.0 \\
\hline \multirow[t]{3}{*}{ Phenols } & OMIY-bisphenol & $1943-97-1$ & NAd & NA & $-0.3^{9}$ & - & - & - \\
\hline & p-n-Nonylphenol & $104-40-5$ & -1.5 & NA & -5.0 & -5.0 & -5.0 & -5.0 \\
\hline & Bisphenol A & $80-05-7$ & -1.5 & -3.1 & -1.6 & -2.6 & -3.2 & -5.0 \\
\hline \multirow[t]{3}{*}{ Organochlorines } & Kepone & $143-50-0$ & -1.5 & -3.2 & -1.0 & -1.7 & -0.7 & -5.0 \\
\hline & $o, p^{\prime}-\mathrm{DDT}$ & $789-02-6$ & -1.7 & -3.1 & -3.5 & -5.0 & -5.0 & -5.0 \\
\hline & $2,4,5-\mathrm{T}$ & $93-76-5$ & -5.0 & NA & NA & -5.0 & -5.0 & -5.0 \\
\hline \multirow[t]{2}{*}{ Phthalates } & $\begin{array}{l}\text { Butylbenzyl } \\
\text { phthalate }\end{array}$ & $85-68-7$ & -2.7 & -3.8 & -5.0 & -5.0 & -5.0 & -5.0 \\
\hline & $\begin{array}{l}\text { Di- } n \text {-butyl } \\
\text { phthalate }\end{array}$ & $84-74-2$ & -2.6 & -2.6 & -5.0 & -5.0 & -5.0 & -5.0 \\
\hline Paraben & Ethyl paraben & $120-47-8$ & -3.2 & -4.9 & -5.0 & -5.0 & -5.0 & 1.9 \\
\hline \multirow[t]{2}{*}{ SERMs } & Tamoxifen & $10540-29-1$ & 0.6 & NA & 1.0 & - & - & - \\
\hline & $\begin{array}{l}\text { 4-Hydroxy- } \\
\text { tamoxifen }\end{array}$ & $68047-06-3$ & 2.2 & NA & 1.0 & - & - & - \\
\hline
\end{tabular}

a Logarithm of the median ER relative binding affinity values listed in the review of ICCVAM (ICCVAM, 2003).

b Median logRBA value derived from the EDKB (National Center for Toxicological Research, USA) (Ding et al., 2010).

$c$ A cut-off value of -5.0 is listed for compounds showing no effect.

d Data not available

e Relative estrogenic potency is defined as the ratio between the $\mathrm{EC}_{50}$ of $17 \beta$-estradiol and the $\mathrm{EC}_{50}$ of the compound, and this ratio is subsequently multiplied by 100 , calculated based on the BG1Luc ER TA data reported by ICCVAM (ICCVAM, 2011). The REP value of $17 \beta$-estradiol is thus 100 , resulting in a logREP of 2.0 .

${ }^{f}$ Median relative potency values based on uterotrophic assay in mouse or rat, derived from the EDKB (NCTR, USA). 17 $\beta$-Estradiol is used as a reference chemical and is defined to have a relative potency of 100 (logRP=2.0) (Ding et al., 2010).

9 LogRP of 4,4'-(octahydro-4,7-methano-5H-inden-5-ylidene)bisphenol was calculated based on the minimal active dose described by Yamasaki et al. (2003).

$\mathrm{h}$ Relative binding potency values are obtained from the ratio of the concentration of $17 \beta$-estradiol needed to achieve $50 \%$ of maximal binding of ERa-LBD to coregulator and the concentration of the test compounds required to achieve a similar effect, and this ratio is subsequently multiplied by 100 . The RBP value of $17 \beta$-estradiol is thus 100 , resulting in a logRBP of 2.0.

i Compound showing only antagonist binding effect; therefore, the logRBP value cannot be determined. 
tivator binding signals compared to the known ER agonists and the solvent control DMSO. The binding profiles of these SERMs are thus unique, as they are almost opposite to the profiles obtained with the known ER agonists and different from the profiles obtained with the negative controls and DMSO solvent control, indicating that the antagonistic properties of these SERMs mainly result from blocking the interaction of $E R \alpha$ with coactivator peptides rather than recruitment of corepressors. These findings are in agreement with other studies, showing that tamoxifen and 4-hydroxytamoxifen bind to the ligand-binding domain of ER $\alpha$ and cause a conformational shift of helix 12 into an adjacent coactivator site, which in turn prevents ER $\alpha$ from binding a coactivator (Shiau et al., 1998; Klinge et al., 2001; Pike et al., 1999; Konge et al., 2005; Kojetin et al., 2008). Moreover, the calculated $\mathrm{IC}_{50}$ values, based on all the coregulators showing a very good fit of the standard dose-response model, were $2.55 \times 10^{-7} \mathrm{M}$ and $1.82 \times 10^{-9} \mathrm{M}$ for tamoxifen and 4-hydroxytamoxifen, respectively. These $\mathrm{IC}_{50}$ values are also in line with data reported by ICCVAM, i.e., $7.12 \times 10^{-7} \mathrm{M}$ and $4.94 \times 10^{-9}$ $M$ for tamoxifen and 4-hydroxytamoxifen, respectively, in the BG1Luc ER transcriptional activation assay, demonstrating that the coregulator binding assay also is useful to test anti-estrogenic properties of compounds. Although tamoxifen and 4-hydroxytamoxifen are mainly reported to act as ER antagonists in breast and as ER agonists in uterus tissue (Shang and Brown, 2002), they are also able to inhibit the effect caused by EE2 in the uterotrophic assay and to induce breast cell proliferation in the E-screen (Fang et al., 2000; Yamasaki et al., 2003; Wang et al., 2012). The OMIY-bisphenol shows both agonistic and antagonistic effects in the uterotrophic assay, and when tested in proliferation assays it also behaves as an agonist and antagonist, demonstrating a biological effect profile nearly identical to tamoxifen (Wang et al., 2012). Thus, transcriptional activation assays, cell proliferation assays, and the in vivo uterotrophic assay are capable of displaying both the ER agonistic and ER antagonistic properties of tamoxifen, 4-hydroxytamoxifen, and OMIY-bisphenol. However, when tested on the peptide microarray, these three compounds showed only antagonistic effects. It is highly unlikely that the profiles will reveal the agonistic properties of these SERMs when co-exposed with E2 or EE2.

The androgen testosterone (T) was used as a negative control, as it is inactive in the in vivo uterotrophic assay. In the coregulator binding assay, $\mathrm{T}$ clearly induced the binding of ER $\alpha$-LBD to several coactivators (e.g., binding of NCOA1_677_700 resulted a $\operatorname{logRBP}$ value of -3.0). However, in several studies it was shown that $\mathrm{T}$ can induce cell proliferation in MCF-7/BOS cells (E-screen), and it has been demonstrated that this atypical response was mediated by activation of the ER. More specifically, the proliferative response induced by testosterone in the E-screen is partially due to its conversion into $17 \beta$-estradiol by aromatase (Wang et al., 2012), partially due to formation of other estrogenic metabolites (Wang et al., 2013), and also partially due to T, i.e., activation of ER $\alpha$. These findings are in line with the observations in the present study, i.e., $\mathrm{T}$ is capable of activating ER $\alpha$-LBD and induces subsequent binding of several coactivators. Moreover, when tested in a yeast estrogen bioassay lacking steroid metabolism and steroidogenesis enzymes $\mathrm{T}$ was also shown to elicit weak responses at very high concentrations (Bovee et al., 2004), once again confirming that $\mathrm{T}$ is able to activate the ER $\alpha$ in vitro.

The environmental pollutant p- $n$-nonylphenol (CAS nr.10440-5) was included by ICCVAM as a positive control in a set of reference compounds for validation of in vitro ER binding and transcriptional activation assays (ICCVAM, 2003). In our coregulator binding assay, this compound did not show any response. However, although others reported $p$-n-nonylphenol to be active in transcriptional activation assays based on either yeast cells or mammalian cells (Gaido et al., 1997; Legler et al., 1999), a thorough review of these studies showed that a technical mixture like the one available from Fluka (approximately $85-92.7 \%$ of branched isomers) or p-nonylphenol (CAS No. 84852-15-3) was used instead of the unbranched nonyl chain (CAS nr.104-40-5). Thus, the ICCVAM report may need to be updated in this regard. Meanwhile, it has been shown that the $p$-n-nonylphenol (CAS nr.104-40-5) was inactive in a yeast estrogen bioassay, while a technical mixture of nonylphenol from Fluka was active in the estrogen yeast bioassay (Bovee et al., 2004). From this, it could be concluded that $p$-n-nonylphenol is not estrogenic and that the estrogenicity of the technical mixture is due to one or more isomers with a branched side-chain. A similar conclusion was presented by Pedersen et al. (1999) studying the induction of plasma vitellogenin in rainbow trout by linear and technical nonyl- and octylphenol. In a more recent study, $p$-n-nonylphenol was even used as a negative control for the validation of a recombinant yeast estrogen receptor agonist assay (Kolle et al., 2010). Moreover, butylbenzyl phthalate, di- $n$-butyl phthalate, and ethyl paraben were reported to bind weakly to the ER and were also slightly active in the BG1Luc ER transcriptional activation assay (ICCVAM, 2003, 2011). In the coregulator binding assay, although they may also bind weakly to the ER $\alpha$-LBD, detectable coregulator recruitment was not induced by these compounds under the concentrations tested. In the in vivo uterotrophic assay, butylbenzyl phthalate, di- $n$-butyl phthalate and ethyl paraben also are not able to induce uterotrophic effects (Zacharewski et al., 1998; Sik Kim et al., 2005; Hossaini et al., 2000). This demonstrated that the human cancer cell line based reporter gene assays are more sensitive than both the in vivo uterotrophic assay and the current coregulator binding assay, which is an advantage for screening estrogenicity in food or environmental samples. However, for prioritization and testing pure chemicals, all these in vitro assays are sensitive enough to measure potent to weak estrogens. Compounds that are negative in the coregulator binding assay, although slightly active in the BG1Luc ER assay, may not have the highest priority to be further tested for estrogenicity in the in vivo uterotrophic assay. In addition, $o, p$ '-DDT is able to induce a uterotrophic effect in the rat (Shelby et al., 1996; Newbold et al., 2001), but did not show an effect in the current coregulator binding assay. This is probably due to the narrow concentration range tested (20 pM-200 $\mu \mathrm{M})$, resulting in poor fitting of the applied dose-response model to the data, and as a consequence, classification of the response of $o, p$ '-DDT as negative. With excellent correlation with the estrogen receptor binding as- 
Tab. 2: Correlation of the relative potencies obtained in the ER binding assay, BG1Luc ER transcriptional activation assay, and in vivo uterotrophic assay with those obtained in the coregulator binding assay based on 57 coactivators showing a clear sigmoidal dose-response relation for $17 \beta$-estradiol-induced binding of ERa-LBD as reflected by a goodness-of-fit value of 0.9 or higher

\begin{tabular}{|c|c|c|c|c|c|}
\hline \multirow{2}{*}{ Coregulator binding assay Peptide ID } & \multirow[t]{2}{*}{ Motif } & \multirow[t]{2}{*}{ Uniprot Accession } & \multicolumn{3}{|c|}{ Coefficient of determination $\left(\mathbf{R}^{2}\right)$} \\
\hline & & & $\begin{array}{l}\text { ER binding } \\
\text { assay }(n=19)\end{array}$ & $\begin{array}{l}\text { BG1Luc } \\
\text { ER TA } \\
(n=16)\end{array}$ & $\begin{array}{l}\text { In vivo } \\
\text { uterotrophic } \\
\text { assay }(n=18)\end{array}$ \\
\hline BL1S1_1_11 & LxxLL2 & P78537 & 0.51 & 0.54 & 0.49 \\
\hline BRD8_254_276 & LxxLL267 & Q9H0E9 & 0.74 & 0.80 & 0.87 \\
\hline CBP_57_80 & LxxLL70 & Q92793 & 0.65 & 0.84 & 0.71 \\
\hline EP300_69_91 & LxxLL81 & Q09472 & 0.73 & 0.82 & 0.84 \\
\hline GNAQ_21_43 & LxxLL34 & P50148 & 0.80 & 0.81 & 0.86 \\
\hline HAIR_745_767_C755S/C759S & LxxLL758 & 043593 & 0.46 & 0.53 & 0.46 \\
\hline IKBB_277_299 & LxxLL289 & Q15653 & 0.80 & 0.78 & 0.82 \\
\hline JHD2C_2054_2076 & LxxLL2066 & Q15652 & 0.85 & 0.79 & 0.88 \\
\hline LCOR_40_62 & LxxLL53 & Q96JN0 & 0.64 & 0.84 & 0.81 \\
\hline MED1_591_614 & LxxLL604 & Q15648 & 0.69 & 0.80 & 0.81 \\
\hline MLL2_4175_4197 & LxxLL4188 & 014686 & 0.65 & 0.81 & 0.79 \\
\hline NCOA1_620_643 & LxxLL633 & Q15788 & 0.82 & 0.80 & 0.87 \\
\hline NCOA1_677_700 & LxxLL690 & & 0.87 & 0.76 & 0.89 \\
\hline NCOA1_737_759 & LxxLL749 & & 0.78 & 0.81 & 0.83 \\
\hline NCOA1_1421_1441 & LxxLL1435 & & 0.84 & 0.74 & 0.89 \\
\hline NCOA2_628_651 & LxxLL641 & Q15596 & 0.86 & 0.75 & 0.88 \\
\hline NCOA2_677_700 & LxxLL690 & & 0.84 & 0.80 & 0.87 \\
\hline NCOA2_733_755 & LxxLL745 & & 0.82 & 0.81 & 0.87 \\
\hline NCOA3_609_631 & LxxLL621 & Q9Y6Q9 & 0.79 & 0.82 & 0.85 \\
\hline NCOA3_609_631_C627S & LxxLL621 & & 0.86 & 0.78 & 0.89 \\
\hline NCOA3_673_695 & LxxLL685 & & 0.85 & 0.78 & 0.89 \\
\hline NCOA3_725_747 & LxxLL738 & & 0.85 & 0.78 & 0.89 \\
\hline NR0B1_1_23 & LxxML13 & P51843 & 0.78 & 0.81 & 0.82 \\
\hline NR0B1_136_159 & LxxLL146 & & 0.83 & 0.75 & 0.83 \\
\hline NR0B2_9_31_C9S/C11S & LxxLL21 & Q15466 & 0.82 & 0.76 & 0.84 \\
\hline NR0B2_106_128 & LxxIL118 & & 0.83 & 0.71 & 0.89 \\
\hline NR0B2_201_223_C207S & LxxVL214 & & 0.78 & 0.80 & 0.82 \\
\hline NRBF2_128_150 & LxxLL141 & Q96F24 & 0.64 & 0.77 & 0.66 \\
\hline NRIP1_120_142 & LxxLL133 & P48552 & 0.78 & 0.80 & 0.85 \\
\hline NRIP1_121_143_P124R & LxxLL133 & & 0.64 & 0.81 & 0.78 \\
\hline NRIP1_253_275_C263S & LxxLL266 & & 0.81 & 0.80 & 0.88 \\
\hline NRIP1_368_390 & LxxLL380 & & 0.84 & 0.73 & 0.84 \\
\hline NRIP1_488_510 & LxxLL501 & & 0.83 & 0.80 & 0.89 \\
\hline
\end{tabular}




\begin{tabular}{|c|c|c|c|c|c|}
\hline \multirow{2}{*}{ Coregulator binding assay Peptide ID } & \multirow[t]{2}{*}{ Motif } & \multirow[t]{2}{*}{ Uniprot Accession } & \multicolumn{3}{|c|}{ Coefficient of determination $\left(\mathbf{R}^{2}\right)$} \\
\hline & & & $\begin{array}{l}\text { ER binding } \\
\text { assay }(n=19)\end{array}$ & $\begin{array}{l}\text { BG1Luc } \\
\text { ER TA } \\
(n=16)\end{array}$ & $\begin{array}{l}\text { In vivo } \\
\text { uterotrophic } \\
\text { assay }(\mathrm{n}=18)\end{array}$ \\
\hline NRIP1_700_722 & LxxLL713 & & 0.81 & 0.80 & 0.87 \\
\hline NRIP1_701_723 & LxxLL713 & & 0.81 & 0.81 & 0.88 \\
\hline NRIP1_805_831 & LxxLL819 & & 0.81 & 0.80 & 0.88 \\
\hline NRIP1_924_946 & LxxLL936 & & 0.80 & 0.82 & 0.87 \\
\hline NRIP1_924_946_C945S & LxxLL936 & & 0.84 & 0.80 & 0.88 \\
\hline NRIP1_1055_1077 & LxxML1068 & & 0.84 & 0.79 & 0.89 \\
\hline NSD1_894_916 & FxxLL907 & Q96L73 & 0.62 & 0.81 & 0.74 \\
\hline PELP1_20_42 & LxxLL33 & Q8IZL8 & 0.76 & 0.79 & 0.84 \\
\hline PELP1_168_190 & LxxLL181 & & 0.80 & 0.75 & 0.83 \\
\hline PELP1_446_468 & LxxLL459 & & 0.77 & 0.81 & 0.82 \\
\hline PELP1_571_593_C575S/C581S & LxxLL584 & & 0.83 & 0.71 & 0.84 \\
\hline PPRC1_151_173 & LxxLL164 & Q5VV67 & 0.77 & 0.80 & 0.88 \\
\hline PRGC1_130_155 & LxxLL144 & Q9UBK2 & 0.73 & 0.61 & 0.82 \\
\hline PRGC1_134_154 & LxxLL144 & & 0.80 & 0.72 & 0.80 \\
\hline PRGC2_146_166 & LxxLL156 & Q86YN6 & 0.85 & 0.74 & 0.88 \\
\hline PRGC2_338_358 & LxxLL343 & & 0.83 & 0.80 & 0.88 \\
\hline PROX1_57_79 & LxxLL70 & Q92786 & 0.80 & 0.82 & 0.87 \\
\hline TIF1A_747_769 & LxxLL760 & 015164 & 0.83 & 0.74 & 0.82 \\
\hline TIP60_476_498 & LxxLL489 & Q92993 & 0.78 & 0.82 & 0.84 \\
\hline TREF1_168_190 & LxxLL181 & Q96PN7 & 0.76 & 0.80 & 0.87 \\
\hline TRRAP_3535_3557_C3535S/C3555S & LxxLL3548 & Q9Y4A5 & 0.60 & 0.71 & 0.74 \\
\hline TRXR1_132_154 & LxxLL145 & Q16881 & 0.81 & 0.83 & 0.89 \\
\hline WIPI1_119_141 & LxxLL132 & Q5MNZ9 & 0.60 & 0.76 & 0.78 \\
\hline ZNHI3_89_111 & LxxLL101 & Q15649 & 0.82 & 0.80 & 0.88 \\
\hline
\end{tabular}

a ID as follows: [coregulator]_[aa start]_[aa end of peptide], bold coactivators have been shown previously to bind to endogenous ERa in cell lysates and in breast tumors in the presence of E2 (Houtman et al., 2012).

say (33 coactivators with $\left.\mathrm{R}^{2} \geq 0.80, \mathrm{n}=19\right)$, BG1Luc ER transcriptional activation assay ( 32 coactivators with $R^{2} \geq 0.80$, $\mathrm{n}=16$ ), and the in vivo uterotrophic assay (30 coactivators with $\mathrm{R}^{2} \geq 0.85, \mathrm{n}=18$ ), the coregulator binding assay demonstrated its usefulness in screening substances for in vitro ER agonistic activity. Moreover, 25 coactivators have been shown to bind to endogenous ER $\alpha$ in cell lysates and in breast tumors when tested on a PamChip ${ }^{\circledR}$ plate peptide microarray in the presence of E2 (Houtman et al., 2012). Twenty-one of these 25 coactivators (highlighted in Tab. 2) also display a high correlation coefficient with the estrogenicity observed in the uterotrophic assay, indicating the biological relevance of the correlation found with these coactivators.
In summary, the obtained results in this study with the SERMs indicate that the coregulator binding assay based on the PamChip ${ }^{\circledR}$ plate is able to distinguish receptor agonists from antagonists. Moreover, in transcriptional activation assays, cell proliferation assays and the in vivo uterotrophic assay, the effects of ER antagonists generally are measured in combination with potent estrogens such as E2 or EE2, while in the coregulator binding assay, the antagonist properties can be measured directly, i.e., without the addition of a potent ER agonist. However, although the in vivo antagonist effects of the SERMs (e.g., tamoxifen, 4-hydroxytamoxifen and OMIY-bisphenol) could be predicted correctly, the coregulator binding assay is not able to reveal the ER agonist properties of these SERMs. Therefore, 
other types of in vitro assays, e.g., reporter gene assays and the H295R steroidogenesis assay, are needed to build a panel of in vitro assays to increase the predictive power and to reach a similar performance in qualifying compounds as that achieved by the in vivo uterotrophic assay. The present study thus shows that the coregulator binding assay is useful within such a panel of in vitro test systems for estrogenicity testing, allowing easy highthroughput screening and prioritization of chemicals, thereby contributing to the reduction - and ultimately the replacement - of current animal testing for (anti-)estrogenic effects.

\section{References}

Ascenzi, P., Bocedi, A., and Marino, M. (2006). Structure-function relationship of estrogen receptor [alpha] and [beta]: Impact on human health. Mol Aspects Med 27, 299-402.

Bovee, T. F., Helsdingen, R. J., Rietjens, I. M., et al. (2004). Rapid yeast estrogen bioassays stably expressing human estrogen receptors alpha and beta, and green fluorescent protein: a comparison of different compounds with both receptor types. J Steroid Biochem Mol Biol 91, 99-109.

Bovee, T. F. and Pikkemaat, M. G. (2009). Bioactivity-based screening of antibiotics and hormones. J Chromatogr A 1216, 8035-8050.

Bovee, T. F. H., Bor, G., Becue, I., et al. (2009). Inter-laboratory comparison of a yeast bioassay for the determination of estrogenic activity in biological samples. Anal Chim Acta 637, 265-272.

Breinholt, V., Hossaini, A., Svendsen, G. W., et al. (2000). Estrogenic activity of flavonoids in mice. The importance of estrogen receptor distribution, metabolism and bioavailability. Food Chem Toxicol 38, 555-564.

Brzozowski, A. M., Pike, A. C. W., Dauter, Z., et al. (1997). Molecular basis of agonism and antagonism in the oestrogen receptor. Nature 389, 753-758.

Clode, S. A. (2006). Assessment of in vivo assays for endocrine disruption. Best Pract Res Clin Endocrinol Metab 20, 35-43.

Couse, J. F. and Korach, K. S. (1999). Estrogen Receptor Null Mice: What Have We Learned and Where Will They Lead Us? Endocr Rev 20, 358-417.

Ding, D., Xu, L., Fang, H., et al. (2010). The EDKB: an established knowledge base for endocrine disrupting chemicals. BMC Bioinformatics 11, S5.

EC - European Commission (2006). Regulation (EC) No 1907/2006 of the European Parliament and of the Council 18 December 2006 concerning the Registration, Evaluation, Authorisation and Restriction of Chemicals (REACH), establishing a European Chemicals Agency, amending Directive 1999/45/EC and repealing Council Regulation (EEC) No 793/93 and Commission Regulation (EC) No 1488/94 as well as Council Directive 76/769/EEC and Commission Directives 91/155/EEC, 93/67/EEC, 93/105/EC and 2000/21/EC.

Fang, H., Tong, W., Perkins, R., et al. (2000). Quantitative comparisons of in vitro assays for estrogenic activities. Environ Health Perspect 108, 723-729.
Gaido, K. W., Leonard, L. S., Lovell, S., et al. (1997). Evaluation of Chemicals with Endocrine Modulating Activity in a Yeast-Based Steroid Hormone Receptor Gene Transcription Assay. Toxicol Appl Pharmacol 143, 205-212.

Gustafsson, J. (1999). Estrogen receptor beta--a new dimension in estrogen mechanism of action. J Endocrinol 163, 379-383.

Harris, H. A., Katzenellenbogen, J. A., and Katzenellenbogen, B. S. (2002). Characterization of the Biological Roles of the Estrogen Receptors, ER $\alpha$ and ER $\beta$, in Estrogen Target Tissues in Vivo through the Use of an ER $\alpha$-Selective Ligand. Endocrinology 143, 4172-4177.

Heldring, N., Pike, A., Andersson, S., et al. (2007). Estrogen Receptors: How Do They Signal and What Are Their Targets. Physiol Rev 87, 905-931.

Hilhorst, R., Houkes, L., van den Berg, A., et al. (2009). Peptide microarrays for detailed, high-throughput substrate identification, kinetic characterization, and inhibition studies on protein kinase A. Anal Biochem 387, 150-161.

Hossaini, A., Larsen, J. J., and Larsen, J. C. (2000). Lack of oestrogenic effects of food preservatives (parabens) in uterotrophic assays. Food Chem Toxicol 38, 319-323.

Houtman, R., de Leeuw, R., Rondaij, M., et al. (2012). Serine-305 Phosphorylation Modulates Estrogen Receptor Alpha Binding to a Coregulator Peptide Array, with Potential Application in Predicting Responses to Tamoxifen. Mol Cancer Ther 11, 805-816.

Hsia, E. Y., Goodson, M. L., Zou, J. X., et al. (2010). Nuclear receptor coregulators as a new paradigm for therapeutic targeting. Adv Drug Deliv Rev 62, 1227-1237.

ICCVAM (2003). Evaluation of In Vitro Test Methods for Detecting Potential Endocrine Disruptors: Estrogen Receptor and Androgen Receptor Binding and Transcriptional Activation Assays. NIH Publication No: 03-4503. Research Triangle Park, NC: National Institute of Environmental Health Sciences.

ICCVAM (2011). Test Method Evaluation Report. The LUMICELL ${ }^{\circledR}$ ER (BG1Luc ER TA) Test Method: An In Vitro Assay for Identifying Human Estrogen Receptor Agonist and Antagonist Activity of Chemicals. NIH Publication No. 11-7850. Research Triangle Park, NC: National Institute of Environmental Health Sciences.

Johnson, A. B. and O'Malley, B. W. (2012). Steroid receptor coactivators 1,2, and 3: Critical regulators of nuclear receptor activity and steroid receptor modulator (SRM)-based cancer therapy. Mol Cell Endocrinol 348, 430-439.

Klinge, C. M. (2000). Estrogen receptor interaction with coactivators and co-repressors. Steroids 65, 227-251.

Klinge, C. M., Jernigan, S. C., Smith, S. L., et al. (2001). Estrogen response element sequence impacts the conformation and transcriptional activity of estrogen receptor $\alpha$. Mol Cell Endocrinol 174, 151-166.

Kojetin, D. J., Burris, T. P., Jensen, E. V., et al. (2008). Implications of the binding of tamoxifen to the coactivator recognition site of the estrogen receptor. Endocr Relat Cancer 15, 851-870. 
Kolle, S. N., Kamp, H. G., Huener, H. A., et al. (2010). In house validation of recombinant yeast estrogen and androgen receptor agonist and antagonist screening assays. Toxicol in Vitro 24, 2030-2040.

Kong, E. H., Heldring, N., Gustafsson, J.-Å., et al. (2005). Delineation of a unique protein-protein interaction site on the surface of the estrogen receptor. Proc Natl Acad Sci USA 102, 3593-3598.

Legler, J., van den Brink, C. E., Brouwer, A., et al. (1999). Development of a stably transfected estrogen receptor-mediated luciferase reporter gene assay in the human T47D breast cancer cell line. Toxicol Sci 48, 55-66.

Lemeer, S., Jopling, C., Naji, F., et al. (2007). Protein-Tyrosine Kinase Activity Profiling in Knock Down Zebrafish Embryos. PLoS One 2, e581.

Lonard, D. M. and O'Malley, B. W. (2012). Nuclear receptor coregulators: modulators of pathology and therapeutic targets. Nat Rev Endocrinol 8, 598-604.

Long, X., Fan, M., Bigsby, R. M., et al. (2008). Apigenin inhibits antiestrogen-resistant breast cancer cell growth through estrogen receptor- $\alpha$-dependent and estrogen receptor- $\alpha$ independent mechanisms. Mol Cancer Ther 7, 2096-2108.

McDonnell, D. P. and Wardell, S. E. (2010). The molecular mechanisms underlying the pharmacological actions of ER modulators: implications for new drug discovery in breast cancer. Curr Opin Pharmacol 10, 620-628.

McKenna, N. J., Lanz, R. B., and O’Malley, B. W. (1999). Nuclear Receptor Coregulators: Cellular and Molecular Biology. Endocr Rev 20, 321-344.

Mueller, S. O., and Korach, K. S. (2001). Mechanisms of Estrogen Receptor-Mediated Agonistic and Antagonistic Effects. In M. Metzler (ed.), Endocrine Disruptors - Part I (Vol. 3 Series: Anthropogenic Compounds, 1-25). Berlin Heidelberg: Springer.

Newbold, R. R., Jefferson, W. N., Padilla-Banks, E., et al. (2001). Cell response endpoints enhance sensitivity of the immature mouse uterotropic assay. Reprod Toxicol 15, 245-252.

Owens, J. W. and Ashby, J. (2002). Critical Review and Evaluation of the Uterotrophic Bioassay for the Identification of Possible Estrogen Agonists and Antagonists: In Support of the Validation of the OECD Uterotrophic Protocols for the Laboratory Rodent. Crit Rev Toxicol 32, 445-520.

Pedersen, S. N., Christiansen, L. B., Pedersen, K. L., et al. (1999). In vivo estrogenic activity of branched and linear alkylphenols in rainbow trout (Oncorhynchus mykiss). Sci Total Environ 233, 89-96.

Pike, A. C. W., Brzozowski, A. M., Hubbard, R. E., et al . (1999). Structure of the ligand-binding domain of oestrogen receptor beta in the presence of a partial agonist and a full antagonist. EMBO J 18, 4608-4618.

Plotan, M., Elliott, C., Oplatowska, M., et al. (2012). Validation and application of reporter gene assays for the determination of estrogenic and androgenic endocrine disruptor activity in sport supplements. Anal Bioanal Chem 403, 3057-3067.
Shang, Y. and Brown, M. (2002). Molecular Determinants for the Tissue Specificity of SERMs. Science 295, 2465-2468.

Shelby, M. D., Newbold, R. R., Tully, D. B., et al. (1996). Assessing environmental chemicals for estrogenicity using a combination of in vitro and in vivo assays. Environ Health Perspect 104, 1296-1300.

Shiau, A. K., Barstad, D., Loria, P. M., et al. (1998). The Structural Basis of Estrogen Receptor/Coactivator Recognition and the Antagonism of This Interaction by Tamoxifen. Cell 95, 927-937.

Sik Kim, H., Seok Kang, T., Hyun Kang, I., et al. (2005). Validation Study of OECD Rodent Uterotrophic Assay for The Assessment of Estrogenic Activity in Sprague-Dawley Immature Female Rats. J Toxicol Environ Health A 68, 2249-2262.

van der Burg, B., Winter, R., Weimer, M., et al. (2010). Optimization and prevalidation of the in vitro ER $\alpha$ CALUX method to test estrogenic and antiestrogenic activity of compounds. Reprod Toxicol 30, 73-80.

Wang, S., Aarts, J. M. M. J. G., Evers, N. M., et al. (2012). Proliferation assays for estrogenicity testing with high predictive value for the in vivo uterotrophic effect. J Steroid Biochem Mol Biol 128, 98-106.

Wang, S., Rijk, J. C. W., Pen, M. J., et al. (2013). A low-density DNA microchip for the detection of (anti-)estrogenic compounds and their relative potencies. Anal Biochem 435; 83-92.

Willemsen, P., Scippo, M.-L., Kausel, G., et al. (2004). Use of reporter cell lines for detection of endocrine-disrupter activity. Anal Bioanal Chem 378, 655-663.

Yamasaki, K., Takeyoshi, M., Yakabe, Y., et al. (2003). Comparison of the reporter gene assay for ER-alpha antagonists with the immature rat uterotrophic assay of 10 chemicals. Toxicol Lett 142, 119-131.

Zacharewski, T. R., Meek, M. D., Clemons, J. H., et al. (1998). Examination of the in Vitro and in Vitro Estrogenic Activities of Eight Commercial Phthalate Esters. Toxicol Sci 46, 282293.

\section{Acknowledgements}

This project was financially supported by the Netherlands Genomics Initiative (Netherlands Toxicogenomics Centre, grant number 6162500134).

\section{Correspondence to}

Si Wang, MSc

Division of Toxicology

Wageningen University

P.O. Box 8000

6700 EA Wageningen

The Netherlands

Phone: +31 317480256

Fax: +31 317417717

e-mail: si.wang@wur.nl 